\title{
Variation in organophosphate resistance and esterase activity in Culex quinquefasciatus Say from California
}

\author{
Nicole PASTEUR *, G.P. GEORGHIOU and A. ISEKI \\ Department of Entomology, Division of Toxicology and Physiology, \\ University of California, Riverside, CA 92521 USA
}

\begin{abstract}
Summary
Organophosphate resistance in Culex quinquefasciatus Say from California is inherited as a monofactorial character $(R)$ indissociable from a highly active esterase ( $H$ allele) and previous experiments suggested that $H$ and $R$ are not unique alleles but rather a series of alleles that differ in their degree of expressivity. In the present study, 4 strains (A, B, C and D) homozygous for different forms of the $R$ and $H$ genes were isolated. These strains displayed different degrees of resistance and different levels of esterase activity.

Esterase activity as well as resistance increased from one resistant strain to the other. In addition, in the offspring of crosses between the A or B strain and a susceptible (S) strain, esterase activity and resistance $\left(\mathrm{LC}_{50}\right)$ were half those of the resistant parent. The relationship existing between the degree of resistance and esterase activity confirmed that both characters are under the genetic control of the same gene. The hypothesis according to which both esterase activity and resistance levels are the result of an amplification (multiple duplication) of a detoxifying gene is discussed.
\end{abstract}

Key words : Organophosphate resistance, esterase, Culex quinquefasciatus.

\section{Résumé}

Variations de la résistance aux insecticides organophosphorés et de l'activité estérasique chez Culex quinquefasciatus Say de Californie

La résistance aux insecticides organosphosphorés est codée par un gène $(R)$ qui ne peut pas être dissocié du gène codant une estérase à grande activité (allèle $H$ ) chez Culex quinquefasciatus Say de Californie. Des expériences antérieures suggéraient que les allèles $H$ et $R$ ne sont pas uniques, mais représentent une série d'allèles différant dans leur expressivité. Dans l'étude présentée ici, 4 souches (A, B, C et D) homozygotes pour des formes différentes des gènes $H$ et $R$ ont été isolées. Ces souches montrent des degrés différents de résistance et d'activité estérasique.

(*) Present address : Institut des Sciences de l'Evolution (LA 327), Laboratoire de Génétique, Université de Montpellier II, place E.-Bataillon, F 34060 Montpellier. 
L'activité de l'estérase (ainsi que le degré de résistance) augmente d'une souche à l'autre. De plus, dans la descendance de croisements entre la souche $A$ ou B et une souche sensible (S), l'activité estérasique et la résistance $\left(\mathrm{LC}_{50}\right.$ ) sont égales à la moitié de celle des parents résistants. La relation existant entre l'activité estérasique et le degré de résistance confirme que les 2 caractères sont sous le contrôle d'un même gène. L'hypothèse selon laquelle l'augmentation graduelle de l'activité estérasique (et de la résistance), ainsi que les résultats des croisements entre les souches résistantes $A$ ou $B$ et la souche sensible, résulte de l'amplification (duplication multiple) du gène de détoxification, est discutée.

Mots clés : Résistance aux organophosphates, estérases, Culex quinquefasciatus.

\section{Introduction}

In Culex quinquefasciatus Say (= Culex pipiens quinquefasciatus) from Califormia, resistance to organophosphate (OP) compounds is inherited as a monofactorial character $(R$ gene) that codes for increased esterase detoxication (RANASINGHE, 1976 ; RANASINGHE \& GeORghiou, 1979). In these resistant mosquitoes, GeORGHIOU \& PASTEUR (1978) observed after electrophoresis of single individuals an esterase with an abnormally high activity towards $\beta$-naphthyl-acetate as compared to the esterases of susceptible insects. The highly active esterase (H-esterase) was shown to be a) coded by a single dominant gene so that mosquitoes with the $\mathrm{H}$-esterase are either $\mathrm{H} / \mathrm{H}$ homozygotes or $\mathrm{H} / \mathrm{O}$ heterozygotes and those without it are $\mathrm{O} / \mathrm{O}$ homozygotes $(" \mathrm{H}$ " for high activity " $\mathrm{O}$ " for no high activity), and b) genetically indissociable from the resistance $R$ factor (GEORGHIOU et al., 1980). Thus $R$ and $H$ might be an identical allele of the same gene, but until now only circumstantial evidence has supported this hypothesis.

PASTEUR et al. (1980) suggested that the $R$ gene exists in different states, each state being responsible for a given level of resistance. GEORGHIOU \& PASTEUR (1980) observed that the activity of the $\mathrm{H}$-esterase varies considerably in mosquitoes of a natural population. The offspring of single pair crosses obtained from parents with the lowest $\mathrm{H}$-esterase activity displayed an OP resistance consistently lower than the offspring of parents with the highest $\mathrm{H}$-esterase activity. These data suggested that $H$ and $R$ are not unique alleles but rather a series of alleles that differ in their expressivity, and that the degree of expression of $\mathrm{H}$-esterase and resistance are correlated.

In the present study, we have isolated strains that can contain a single form of $H$ and $R$ genes, and we have analyzed the relation that exists between esterase activity and the degree of resistance. We show that they are related and suggest that the different levels of resistance, or of esterase activity, might be the result of an amplification (multiple duplication) of the detoxifying esterase gene.

\section{Material and methods}

Three Culex quinquefasciatus strains were used: S-Lab, an OP-susceptible (SS) strain in which all mosquitoes have esterases of low activity ( $O / O$ genotypes) ; Tem-R (previously named Han-74-40 by PASTEUR et al., 1980) homozygous for both OP resistance $(R R)$ and the $H$-esterase $(H / H$ genotypes) ; and RIV, collected from a natural 
population in Riverside during the summer of 1979. The RIV strain was polymorphic for both the presence of the H-esterase ( $H$ and $O$ alleles) and OP resistance ( $R$ and $S$ alleles) (Z. AL-KHATIB, unpubl. data).

Eight strains were established by inbreeding the offspring of single pair crosses done between $\mathrm{H} / \mathrm{O}$ females and $\mathrm{O} / \mathrm{O}$ males. All males originated from the S-Lab strain. Each female was an offspring of different single pair cross between RIV or Tem-R strains and the S-Lab strain.

Each strain was allowed to inbreed for 1 to 2 generations and then was selected during the larval stage with $0.01 \mathrm{ppm}(\mathrm{mg} / 1)$ temephos for 6 or 7 generations in order to increase the frequency of both the $H$ and $R$ genes $(0.01 \mathrm{ppm}$ temephos is a concentration that kills all susceptible homozygotes of the S-Lab strain).

Four of the 8 original strains were retained for further studies, for it was apparent that they displayed different levels of OP resistance. Strains A and B were derived from RIV ; strains C and D from Tem-R. Each strain was made homozygous for the $H$ gene by making single pair crosses with mosquitoes that had been exposed to $0.01 \mathrm{ppm}$ temephos and were either $H / O$ heterozygotes or $H / H$ homozygotes. To determine the exact genotype of the parents, the offspring of each cross was split into 3 sets. Set No. 1 was allowed to inbreed without further treatment and was eventually used to start the strain homozygous for the $H$ allele. Set No. 2 was analyzed for esterase genotypes and it allowed crosses between $H / O \times H / O$ parents to be discarded when part of its mosquitoes did not possess the $\mathrm{H}$-esterase. Each female of set No. 3 was crossed to $1 \mathrm{~S}$-Lab male and it was assumed that they came from a $H / H \times H / H$ cross when all of them (at least 15) produced offspring entirely composed of mosquitoes possessing the $\mathrm{H}$-esterase (i.e. $H / O$ genotypes).

Resistance was tested on young 4th instar larvae using standard bioassay techniques described by GEORGHIOU et al. (1966). Esterase phenotypes were determined by using starch electrophoresis of single 4th instar larva or adult homogenates (PASTEUR \& Georghiou, 1980a) or the " filter paper test" (PASTEUR \& GEORGHIOU, 1980b).

Total esterase activity was determined by measuring the rate of formation of 4methyl-umbelliferol (= coumarine) liberated from the hydrolysis of 4-methyl-umbelliferyl-acetate (4-MUA) by crude homogenates of mosquitoes. Absorbance, measured at $340 \mathrm{~nm}$ with a Beckman spectrophotometer, was linear during $15 \mathrm{~min}$ and assays were run during 60 to 700 depending on the strain used. Each assay was conducted in a solution composed of $0.3 \mathrm{ml}$ of a solution containing $5 \mu$ moles of 4-MUA per ml, $0.5 \mathrm{ml}$ of mosquito homogenate and $2.2 \mathrm{ml}$ of $0.5 \mathrm{M}$ phosphate buffer $\mathrm{pH} 6.7$. The homogenates were made by grinding 15 to 22 24-h-old males in a volume of phosphate buffer such that each $\mathrm{ml}$ corresponded to $10 \mathrm{mg}$ of fresh weight ; they were centrifuged $10 \mathrm{~min}$ at about $5000 \mathrm{~g}$. Since temperature appears to be very critical for measuring esterase activity, all assays were conducted on the same day at room temperature (about $25{ }^{\circ} \mathrm{C}$ ), for we did not possess a refrigerated bath; these activities are therefore comparable between themselves but not necessarily to those previously published by PASTEUR et al. (1981a). 


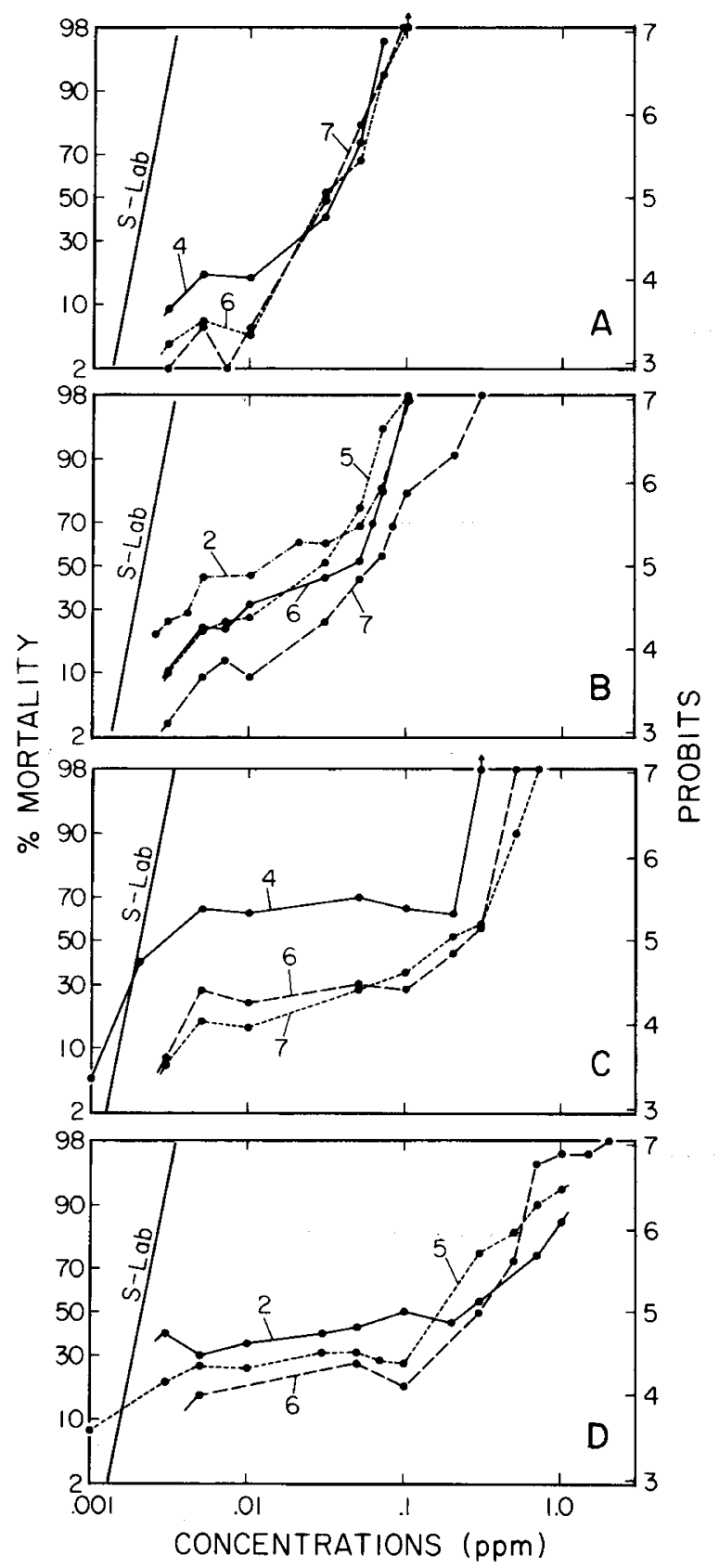

FIG. 1

Dosage-mortality lines for temephos in strains $A, B, C$ and $D$.

Numbers indicate successive generations under selection by temephos.

Courbes de mortalité à différentes doses de temephos au cours de la sélection des souches $A, B, C$ et $D$. Les numéros indiquent la génération de sélection. 


\section{Results}

\section{A. Temephos resistance in various strains}

The strains isolated for the present study were selected for the presence of the highly active esterase (H-esterase) and all segregated for the $R$ and $S$ alleles coding for resistance and susceptibility to $O P$ compounds, respectively. Dosage mortality lines displayed clear horizontal plateaux starting at $0.005 \mathrm{ppm}$ temephos (a concentration that kills all S-Lab susceptible mosquitoes), indicating a mixture of susceptible $(S S)$ and resistant ( $R R$ or $R S$ ) phenotypes. Resistant phenotypes were clearly affected by different temephos concentrations in 4 of the 8 strains isolated originally, as can be seen in comparing the length of the plateaux in figure 1A-D. Since strains A and B originated from single $R S$ female derived from the RIV strain, these differences in OP resistance were due to the different nature of the $R$ gene in the 2 strains, namely by genes $R_{A}$ and $R_{B}$. A similar conclusion is reached with strains $\mathrm{C}$ and $\mathrm{D}$ originated from single $R S$ females derived from the Tem-R strain, i.e. differences in OP resistance are due to $R_{C}$ and $R_{D}$ genes.

In the 4 strains, all mosquitoes that survived $0.01 \mathrm{ppm}$ temephos displayed a $\mathrm{H}$-esterase with the same electrophoretic mobility ; they were therefore $H / H$ homozygotes or $H / O$ heterozygotes. It was assumed that the procedure used to make strains $\mathrm{A}, \mathrm{B}, \mathrm{C}$ and $\mathrm{D}$ homozygous for the $H$ gene had also made them homozygous for $R_{A}$, $R_{B}, R_{C}$ and $R_{D}$, respectively. This was verified on the homozygous strains $\mathrm{A}$ and $\mathrm{B}$ by crossing them to the susceptible S-Lab strain (fig. 2 and 3).

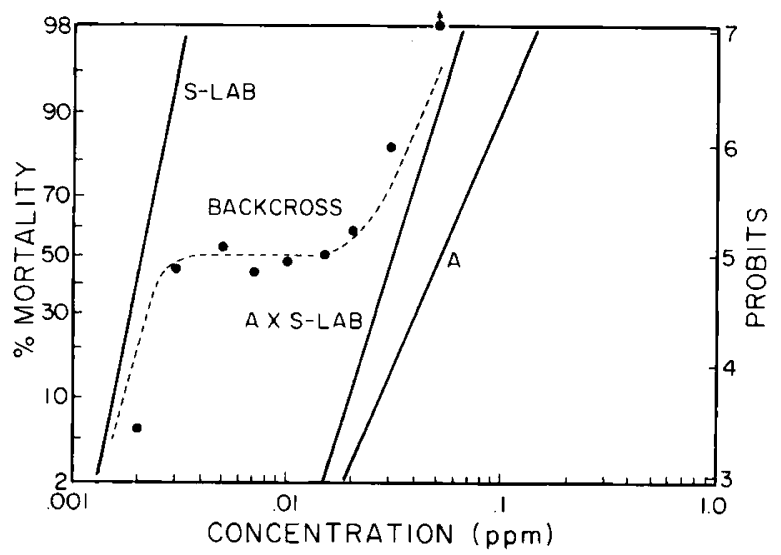

FIG. 2

Dosage-mortality data in strains $A, S$-Lab, and in their $F_{1}$ progeny and $F_{1} \times S$-Lab backcross progeny tested with temephos: $0=$ observed mortality, $---=$ expected mortality on basis of monofactorial inheritance of the resistance factor contained in strain $A$.

Mortalités observées (O) après exposition à différentes doses de temephos dans les souches résistante $A$ et sensible $S$-Lab, ainsi que dans la descendance $A \times S$-Lab, et $(A \times S-L a b) \times S-L a b$

(en pointillés : mortalité attendue si la résistance de la souche $A$ est monofactorielle). 


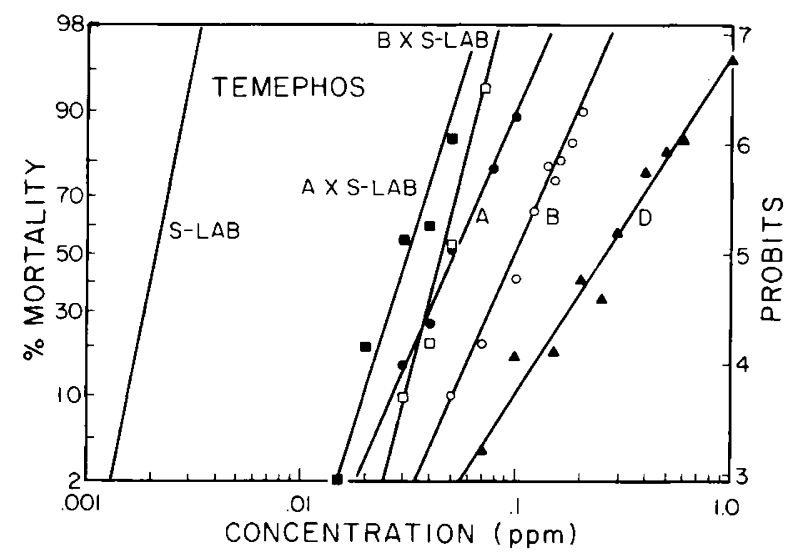

FIG. 3

Dosage-mortality regression lines with temephos for strains S-Lab,

$A, B$ and $D$, and hybrid progeny $A \times S-L a b$ and $B \times S-L a b$.

Régression de la mortalité en fonction de la dose d'exposition au temephos dans les souches $S$-Lab, $A, B$ et $D$, et dans les hybrides $A \times S-L a b$ et $B \times S-L a b$.

Since strains $C$ and D were isolated from the Tem-R strain which was repeatedly shown to contain a single gene for resistance (RANASINGHE, 1976 ; GEORGHIOU et al., $1980), R_{C}$ and $R_{D}$ resistance factors can only be alleles of the same locus. In strains A and $\mathrm{B}$, derived from the RIV population, the level of resistance was more carefully analyzed. In both strains, the level of resistance showed a 100-fold drop when bioassays were carried out in the presence of $2.5 \mathrm{ppm}$ DEF (= S,S,S-tributylphosphorotrithioate). In addition, resistance was shown to be monofactorial in strain A (fig. 2) and also indissociable from the gene coding the H-esterase : all 635 larvae issued from $(\mathrm{A} \times \mathrm{S}$ $\mathrm{Lab}) \times \mathrm{S}$-Lab backcross that survived exposures to $0.01 \mathrm{ppm}$ temephos possessed the $\mathrm{H}$-esterase (i.e., were $\mathrm{H} / \mathrm{O}$ heterozygotes), although 18 of them had a H-esterase of slightly lower activity than normal. Thus, as in strains $\mathrm{C}$ and $\mathrm{D}, \mathrm{OP}$ resistance in strains $A$ and $B$ is due to a single gene coding a detoxifying esterase, and this gene is closely linked or identical to the $H$ gene responsible for the presence of the H-esterase. Since the only difference between the 4 strains is the degree of resistance, it can be concluded that $R_{A}, R_{B}, R_{C}$ and $R_{D}$ resistance factors are alleles of the same $R$ locus. Due to (a) possible differences in the genetic background of strains $A$ and $B$, on one hand, and of strains $\mathrm{C}$ and $\mathrm{D}$, on the other hand, and (b) the possible non-identity of $H$ and $R$ genes, confirmation that $R_{A}$ and $R_{B}$ are alleles distinct from $R_{C}$ and $R_{D}$ is needed.

\section{B. Esterase activity in strains $A, B, C, D$ and Tem-R}

The electrophoretic pattern of H-esterase in strains A, B, C, D and Tem- R mosquitoes was identical and demonstrates a single strongly stained spot in the presence of $\alpha$ - and $\beta$-naphthyl acetates. (Such an enzyme does not exist in mosquitoes of the susceptible S-Lab strain that possess only faintly stained esterase bands.) No difference in the electrophoretic mobilities was noted between strains but there were some variations in their staining intensity. In particular, the H-esterase from strains $D$ and Tem- $R$ was significantly more intensely stained than that from strain A. 
Electrophoretic investigations are not adequate to compare accurately enzyme activities since many factors cannot be controlled. PASTEUR et al. (1981a) showed that the total esterase activity measured as the rate of hydrolysis of a fluorescent ester (4-MUA) is extremely low in susceptible insects. Such a measurement when performed on resistant insects gives a good approximation of the activity due to the $\mathrm{H}$-esterase.

Total esterase activity (tabl. 1) was measured in 24-h-old males obtained from the 2nd generation of homozygosity in A to D strains as well as in the offspring of strains $A$ and $B$ crossed with S-Lab, and in the Tem-R strain from which strains $C$ and $D$ were isolated.

\title{
TABLE 1
}

\begin{abstract}
Organophosphate resistance and esterase activity observed in different strains and crosses of Culex quinquefasciatus.

$L_{50}$, expressed in ppm ( $\left.\mathrm{mg} / \mathrm{l}\right)$, were determined on larvae of the same generation as the adults used to estimate esterase activity.
\end{abstract}

Résistance aux organophosphates et activité estérasique observées

dans différentes souches ou croisements de Culex quinquefasciatus.

Les $L C_{50}$, exprimées en ppm $(\mathrm{mg} / 1)$, ont été déterminées sur des larves de la même génération que les adultes utilisés pour mesurer l'activité estérasique.

\begin{tabular}{|c|c|c|c|c|}
\hline Strains or crosses & $\begin{array}{l}\text { Organophosphate } \\
\text { LC }_{50}\end{array}$ & $\begin{array}{l}\text { Resistance } \\
\text { Slope }\end{array}$ & $\begin{array}{c}\text { Esterase activity } \\
\text { ( } \mu \text { moles/min./ } \\
\text { Mosq.) }\end{array}$ & $\begin{array}{l}\mathrm{LC}_{50} / \text { esterase } \\
\text { activity ratios }\end{array}$ \\
\hline S-Lab . . . . . . & 0.0022 & 5.01 & $0.0099 \pm 0.0008$ & 0.222 \\
\hline $\mathrm{A} \times \mathrm{S}-\mathrm{Lab} \ldots \ldots$ & $\begin{array}{c}0.031 \\
(0.025-0.036)\end{array}$ & 4.90 & $0.0302 \pm 0.0026$ & 1.026 \\
\hline$\ldots \ldots \ldots \ldots$ & $\begin{array}{c}0.056 \\
(0.049-0.063)\end{array}$ & 3.99 & $0.0445 \pm 0.0014$ & 1.258 \\
\hline B $\times$ S-Lab $\ldots \ldots$ & $\begin{array}{c}0.048 \\
(0.035-0.077)\end{array}$ & 6.43 & $0.0387 \pm 0.0021$ & 1.240 \\
\hline B $\ldots \ldots$ & $\begin{array}{c}0.103 \\
(0.098-0.108)\end{array}$ & 4.43 & $0.0836 \pm 0.0064$ & 1.232 \\
\hline & - & - & $0.1581 \pm 0.0038$ & - \\
\hline $\mathrm{D} \ldots \ldots \ldots$ & - & - & $0.2760 \pm 0.0324$ & - \\
\hline Tem-R . . . . . & - & - & $0.3321 \pm 0.0127$ & - \\
\hline
\end{tabular}

$\mathrm{LC}_{50}$ and slope of strains $\mathrm{C}, \mathrm{D}$ and Tem-R are not given here for they were not calculated on mosquitoes of the same generation than those used to measure esterase activity (see text).

It appears that esterase activity varies widely in the different strains homozygous for the presence of the $\mathrm{H}$-esterase (from 0.04 to $0.33 \mu$ mole of 4-MUA per minute and per mosquito in $A$ and Tem- $R$ strains, respectively). This increase in esterase activity is roughly 2 fold from one strain to the other (when strains A through D are considered) and is associated with comparable increases in $\mathrm{LC}_{50}$ values. (In tabl. 1, LC $\mathrm{L}_{50}$ values of strains $C, D$ and Tem-R are not given for they were not obtained on the larvae of the same generation as the adults used to analyse esterase activity; nevertheless, figure 1C-D seems to indicate that resistant insects of strain $\mathrm{C}$ were affected by lower temephos concentrations than resistant insects of strain D.) 
Tem-R LC $_{50}$ was estimated to be $1.10 \mathrm{ppm}$ temephos by GEORGHIOU et al., 1980 , one year before the present experiment, at a time when the selection doses applied each generation were much lower than those used here.

Thus different states of resistance, $R_{A}, R_{B}, R_{C}, R_{D}$ and $R_{r}$ (for the Tem-R strain) correspond to different levels of $\mathrm{H}$-esterase activity. Since the highly active $\mathrm{H}$-esterase has the same electrophoretic mobility in all strains, it was concluded that the $H$ gene corresponds to a series of alleles $H_{A}, H_{B}, H_{C}, H_{D}$ and $H_{T}$. Note that since strains $\mathrm{C}$ and $\mathrm{D}$ are derived from the Tem-R strain, the $H_{T}$ allele may itself be a mixture of several alleles or is spontaneously converted to $H_{C}$ or $H_{D}$ alleles at an exceedingly high rate.

Finally, H-esterase activities (as well as $\mathrm{LC}_{50}$ values) in $\mathrm{F} 1$ offspring of strains $\mathrm{A}$ and $B$ crossed with the susceptible S-Lab strain are roughly half that of the parental resistant strain showing that $\mathrm{H}$-esterase activity (and $\mathrm{LC}_{50}$ value) is correlated with the number of $H_{A}$ or $H_{B}$ alleles present in each individual. It can also be noted that esterase activity in $H_{B} / O$ mosquitoes (i.e. offspring of strains $\mathrm{B} \times \mathrm{S}$-Lab) is similar to the activity in $H_{A} / H_{A}$ (strain A) mosquitoes.

\section{TABLE 2}

Comparative susceptibility of strains of Culex quinquefasciatus to organophosphate insecticides.

Comparaison de la résistance à divers insecticides organophosphorés dans différentes souches de Culex quinquefasciatus.

\begin{tabular}{|c|c|c|c|c|}
\hline Insecticide & S-Lab & Strain A & Strain B & Strain D \\
\hline $\begin{array}{l}\text { Temephos : } \\
\text { LC }_{50} \ldots \ldots \ldots \ldots \ldots \ldots \ldots \ldots \\
\text { LC }_{95} \ldots \ldots \ldots \ldots \ldots \ldots \ldots \ldots \ldots \\
\text { Slope } \ldots \ldots \ldots \ldots \ldots \ldots \ldots\end{array}$ & $\begin{array}{l}0.0022 \\
0.0032 \\
5.01\end{array}$ & $\begin{array}{l}0.056 \\
0.144 \\
3.99\end{array}$ & $\begin{array}{l}0.103 \\
0.242 \\
4.43\end{array}$ & $\begin{array}{l}0.261 \\
0.962 \\
2.90\end{array}$ \\
\hline $\begin{array}{l}\text { Parathion : } \\
\text { LC }_{\text {s0 }} \ldots \ldots \ldots \ldots \ldots \ldots \ldots \ldots \ldots \ldots \ldots \ldots \\
\text { LC }_{95} \ldots \ldots \ldots \ldots \ldots \ldots \ldots \ldots \ldots \\
\text { Slope } \ldots \ldots \ldots \ldots \ldots \ldots\end{array}$ & $\begin{array}{l}0.0033 \\
0.0054 \\
7.69\end{array}$ & $\begin{array}{l}0.020 \\
0.033 \\
7.64\end{array}$ & $\begin{array}{l}0.037 \\
0.077 \\
5.22\end{array}$ & $\begin{array}{l}0.074 \\
0.186 \\
4.12\end{array}$ \\
\hline $\begin{array}{l}\text { Methyl-Parathion : } \\
\text { LC }_{50} \ldots \ldots \ldots \ldots \ldots \ldots \ldots \ldots \ldots \\
\text { LC }_{95} \ldots \ldots \ldots \ldots \ldots \ldots \ldots \ldots \ldots \\
\text { Slope } \ldots \ldots \ldots \ldots \ldots \ldots \ldots \ldots\end{array}$ & $\begin{array}{l}0.0044 \\
0.0071 \\
7.79\end{array}$ & $\begin{array}{l}0.032 \\
0.049 \\
8.73\end{array}$ & $\begin{array}{l}0.070 \\
0.112 \\
7.84\end{array}$ & $\begin{array}{l}0.303 \\
0.765 \\
4.08\end{array}$ \\
\hline $\begin{array}{l}\text { Chlorpyrifos : } \\
\text { LC }_{50} \ldots \ldots \ldots \ldots \ldots \ldots \ldots \ldots \ldots \\
\text { LC }_{95} \ldots \ldots \ldots \ldots \ldots \ldots \ldots \ldots \ldots \\
\text { Slope } \ldots \ldots \ldots \ldots \ldots \ldots \ldots \ldots\end{array}$ & $\begin{array}{c}0.002 \\
0.026 \\
-\end{array}$ & $\begin{array}{l}0.017 \\
0.031 \\
5.97\end{array}$ & $\begin{array}{l}0.029 \\
0.050 \\
6.82\end{array}$ & $\begin{array}{l}0.238 \\
0.653 \\
3.76\end{array}$ \\
\hline $\begin{array}{l}\text { Chlorpyrifos-methyl : } \\
\text { LC }_{50} \ldots \ldots \ldots \ldots \ldots \ldots \ldots \ldots \ldots \\
\text { LC }_{95} \ldots \ldots \ldots \ldots \ldots \ldots \ldots \ldots \ldots \\
\text { Slope } \ldots \ldots \ldots \ldots \ldots \ldots \ldots \ldots\end{array}$ & $\begin{array}{l}0.0021 \\
0.0030 \\
10.2\end{array}$ & $\begin{array}{l}0.078 \\
0.207 \\
3.86\end{array}$ & $\begin{array}{l}0.167 \\
0.274 \\
7.65\end{array}$ & $\begin{array}{l}1.39 \\
3.91 \\
3.65\end{array}$ \\
\hline $\begin{array}{l}\text { Malathion : } \\
\text { LC }_{\text {s0 }} \ldots \ldots \ldots \ldots \ldots \ldots \ldots \ldots \ldots \\
\text { LC }_{95} \ldots \ldots \ldots \ldots \ldots \ldots \ldots \ldots \\
\text { Slope } \ldots \ldots \ldots \ldots \ldots \ldots \ldots\end{array}$ & $\begin{array}{l}0.082 \\
0.182 \\
4.77\end{array}$ & $\begin{array}{l}0.330 \\
0.536 \\
7.79\end{array}$ & $\begin{array}{l}0.855 \\
1.39 \\
7.76\end{array}$ & $\begin{array}{c}5.19 \\
15.7 \\
3.4\end{array}$ \\
\hline
\end{tabular}




\section{Stability of resistance in strains, $A, B, C$ and $D$, and cross resistance}

In strain $\mathrm{D}$, bioassays performed on the 4 th and subsequent generations after the strain was made homozygous for the $H$ gene disclose $\mathrm{LC}_{50}$ values of only $0.261 \mathrm{ppm}$ temephos (tabl. 2). It can be noted that the temephos dose-response line for strain D was parallel to neither that of the S-Lab strain nor to that of strains A and B (strain $C$ was lost before bioassays were completed), figure 3 . This suggests that the high resistance level of strain $\mathrm{D}$ (and consequently $\mathrm{H}$-esterase activity) was not maintained in the absence of selection pressure. A similar observation was made by LAGUNES (1980) on the Tem- $R$ strain when selection pressure was relaxed.

Although the loss of resistance in the absence of selection pressure might be less accentuated in other strains, it most probably occurred. Some of the resistant offspring of the $(A \times S-L a b) \times S-L a b$ backcross displayed an H-esterase of slightly lower activity than normal, an observation that can only be explained if some of the $H_{A}$ alleles of strain A spontaneously lost part of their activity.

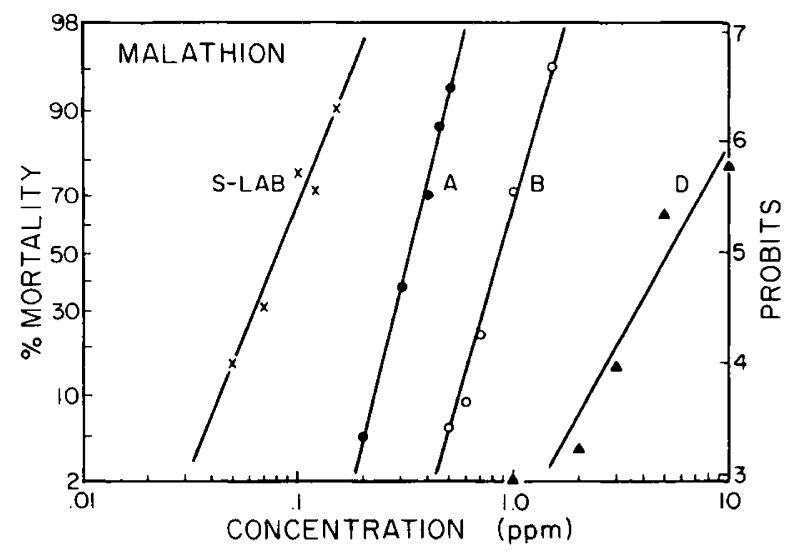

Fig. 4

Dosage-mortality regression lines with malathion for susceptible strain S-Lab, and resistant strains $A, B$ and $D$.

Régression de la mortalité en fonction de la dose d'exposition au malathion dans les souches $A, B$ et $D$.

Strains A, B and D were also resistant to parathion, methyl-parathion, chlorpyrifos, methyl-chlorpyrifos and malathion. As with temephos, resistance to these 5 insecticides was roughly 2 times higher in strain B than in strain A. In all cases resistance in strain D was higher than in strain $B$, but while for temephos and parathion the resistance ratios between strain $B$ and strain $D$ were 2.5 and 2.0 , respectively, they were 3.4 for methyl-parathion, 4.8 for chlorpyrifos, 8.2 for chlorpyrifos-methyl and 6.0 for malathion (tabl. 2, figs 3-5). Since bioassays of strain D were performed over a period of more than 2 months, during which time resistance did not remain constant, it is not possible to know whether these differences in the resistance ratios are due to the fact that each insecticide was not tested at the same time or if they are the result of some fundamental differences in the mechanisms of resistance to each insecticide. 

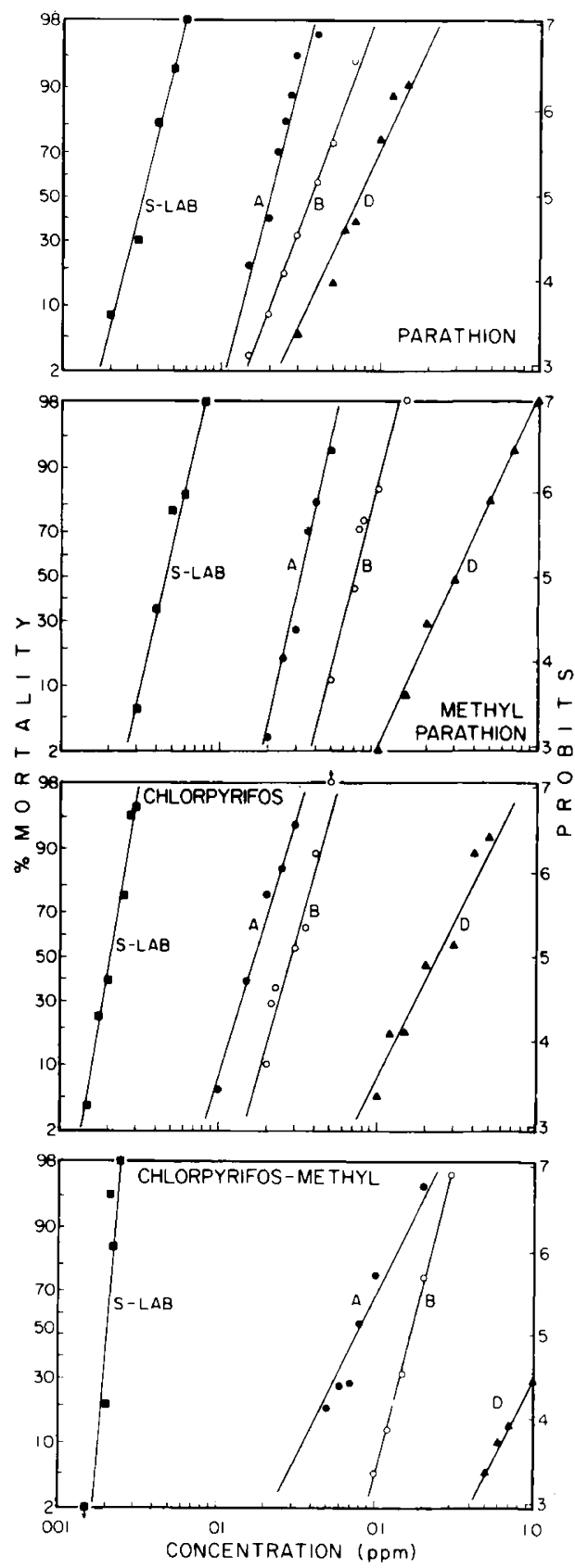

Fig. 5

Dosage-mortality regression lines with 4 organophosphates for susceptible strain S-Lab, and resistant strains $A, B$ and $D$.

Régression de la mortalité en fonction de la dose d'exposition à 4 insecticides organophosphorés dans la souche sensible $S$-Lab et les souches résistantes $A, B$ et $D$. 


\section{Discussion}

Our study has confirmed the hypothesis of PASTEUR et al. (1980) suggesting that, in Culex quinquefasciatus from California, organophosphate resistance is controlled by a series of monofactorial factors of variable efficiency. These factors code a detoxifying esterase (they lose their effect in presence of DEF) and they cannot be genetically separated from the $H$ gene coding the H-esterase revealed by electrophoresis. They, therefore, either represent a series of alleles of a same $R$ gene, or correspond to a series of closely linked genes.

Similarly, the H-esterase revealed by electrophoresis varies in activity, the lowest activity being found in the mosquitoes with the less efficient $R$ gene (A strain) and the highest activity in the mosquitoes with the most efficient $R$ gene (D and Tem-R strains). The fact that the activity of $\mathrm{H}$-esterase is related to the degree of resistance indicates that $\mathrm{H}$-esterase activity and resistance efficiency are under the genetic control of the same gene. In other words, $R_{A}$ and $H_{A}, R_{B}$ and $H_{B}, R_{C}$ and $H_{C}, R_{D}$ and $H_{D}, R_{T}$ and $H_{T}$ behave as identical alleles of a gene controlling the activity of a detoxifying esterase that is revealed after electrophoresis by its activity toward $\beta$-naphthyl acetate. (This gene was identified as Est-2 by PASTEUR et al., 1981a).

Comparison of data obtained in the present study and those reported by PASTEUR et al. (1980) on the Tem-R and related strains suggest that more than 5 alleles of OP resistance are present in natural populations, and we can wonder what genetic mechanism can sustain such a variability.

From the present data, it is evident that these alleles are of a special nature : (a) they provide gradual increase in esterase activity which seems to roughly double from one homozygous strain to the other as is particularly evident when comparing strains A and B ; (b) esterase activity (and therefore resistance) seems to be dependent on the gene dose present in each individual ; and (c) we have indirect evidence that they convert to alleles with lower efficiency at an extremely high rate.

Comparable observations have been reported in OP-resistant strains of Myzus persicae (DEvonshiRe \& SAWICKI, 1979 ; BunTING \& VAN EMDEN, 1980) and in murine cultured cells resistant to methotrexate (Alt et al., 1978). In both cases, a stepwise increase in resistance was demonstrated to be due to increases in quantity of the detoxifying enzymes and was attributed to different degrees of amplification of the gene coding these enzymes : an esterase in the case of Myzus persicae and a dihydrofolate reductase in the case of murine cells.

Our results can also be explained by an amplification of the detoxifying esterase gene ( $E$ gene). If we assume that the homozygous genotype of strain $\mathrm{A}$ is $E / E$, the homozygous genotype of strain $\mathrm{B}$ will be $E E / E E$, which is compatible with the doubling of esterase activity as compared to that of strain A. Hybrids of homozygous resistant $E E / E E$ and homozygous susceptible $O / O$ will be $E E / O$; containing 2 genes $E$, their esterase activity (and their $\mathrm{LC}_{50}$ ) should be similar to that of $E / E$ homozygotes, as is observed. Likewise, strains $C, D$ and Tem-R would contain individuals with a higher number of $E$ genes. This hypothesis is consistent with the observations on OP resistance of Culex quinquefasciatus from California reported by PASTEUR et al. (1980).

Although it is not actually possible to confirm the gene amplification hypothesis in explanation of the various degrees of esterase activity or OP resistance in Californian 
C. quinquefasciatus, we can remark that no other the current hypothesis can explain simply the existence of many apparently regularly spaced degrees of esterase activity.

High esterase activity has been reported in a number of insect species that have become resistant to organophosphorus insecticides. In the Culex pipiens complex it appears that increased activity can occur at 1 or 2 of the 3 esterase genes recognized so far, depending on the geographical origin of the population considered. Thus higher $\mathrm{OP}$ resistance is due to increased esterase activity (a) of the Est-2 gene in Californian populations (present study as well as GEORGHIOU et al., 1980 ; PASTEUR et al., 1981a), (b) of the Est-3 gene in southern French populations (PASTEUR, 1977, PASTEUR et al., 1981a, 1981b), (c) of both Est-2 and Est-3 genes in African and Asiatic populations (Curtis \& PASTEUR, 1981 ; Villani et al., 1983) and (d) of the Est-1 gene in a Nairobi (Kenya) population (VILlANI et al., 1983). Variations in esterase activity and correlated OP resistance have been analyzed by VILLANI et al. (1983) in 1 Asiatic (Colombo, Sri Lanka) and 2 African (Dar-es-Salam, Tanzania) strains, but these authors could not give any support to the gene amplification hypothesis although their data do not give evidence for another mechanism.

Clearly more work has to be done, probably using methodologies different from those of the present study (DNA cloning and enzyme quantities), to understand the genetic mechanism underlying increased esterase activity and correlated OP resistance. However, at the present time, it seems that more than one mechanism is involved. Thus from the present study on Californian strains as well as from the investigation of VILLANI $e t$ al. (1983) on African strains, acquisition of OP resistance through increased esterase activity appears to be a very labile phenomenon : rapid loss occurs when selection pressure is relaxed. On the contrary, in other strains, such as French strain S54 (RAYMOND et al., 1984) OP resistance remains stable for many years in the absence of selection pressure.

\section{Acknowledgements}

The present study was supported by Special Funds for Mosquito Control Research appropriated annually by the Californian Legislature.

Received July 11, 1983.

Accepted March 20, 1984. 


\section{References}

Alt F.W., Kellems R.K., Bertino J.R., SChimke R.T., 1978. Selective multiplication of dihydrofolate reductase genes in methotrexate-resistant variants of cultured murine cells. J. Biol. Chem., 253, 1357-1370.

Bunting S., VAN EMdEN H.F., 1980. Rapid response to selection for increased esterase activity on small populations of an apomictic clone of Myzus persicae. Nature, 285, 502-503.

Curtis C.F., PASTEUR N., 1980. Organophosphate resistance in vector population of the complex of Culex pipiens L. Bull. Entomol. Res., 71, 153-161.

Devonshire A.L., SAwiCKI R.M., 1979. Insecticide resistant Myzus persicae as an exemple of evolution by gene duplication. Nature, 280, 140-141.

Georghiou G.P., MeltCalf R.L., Gidden F.E., 1966. Carbamate resistance in mosquitoes : selection of Culex pipiens fatigans Wied. ( $=C x$. quinquefasciatus) for resistance to Baygon. Bull. W.H.O., 35, 691-708.

Georghiou G.P., PASTEUR N., 1978. Electrophoretic pattern in insecticide resistant and susceptible mosquitoes. J. Econ. Entomol., 71, 201-205.

GeORGHIOU G.P., PASTEUR N., 1980. Organophosphate resistance and esterase pattern in a natural population of the southern house mosquito from California. J. Econ. Entomol., 73, 489-492.

Georghiou G.P., Pasteur N., Hawley M.K., 1980. Linkage relationships between organophosphate resistance and a highly active esterase-B in Culex quinquefasciatus Say from California. J. Econ. Entomol., 73, 301-305.

LAGUNES A., 1980. Impact of the use of mixtures and sequences of insecticides in the evolution of resistance in Culex quinquefasciatus Say (Diptera : Culicidae). Ph. D. dissertation, University of California, Riverside, U.S.A.

PASTEur N., 1977. Recherches de génétique chez Culex pipiens pipiens L. Polymorphisme enzymatique, autogenèse et résistance aux insecticides organophosphorés. Thèse de doctorat d'Etat, Université de Montpellier II, France.

Pasteur N., Georghiou G.P., 1980a. Detection of esterases as a mean of surveying for organophosphate resistance in field populations of Culex pipiens mosquitoes. W.H.O. VBC/EC/80, Geneva 3-9 June 1980, 6 p.

PASTeur N., GeORghiou G.P., 1980b. "Filter paper test " for rapid determination of phenotypes with high esterase activity in organophosphate resistant mosquitoes. Mosquito News, 41, 181-183.

Pasteur N., Georghiou G.P., Ranasinghe L.E., 1980. Variations in degrees of homozygous resistance to organophosphate insecticides in Culex quinquefasciatus Say. 48th Annual Conference of the California Mosquito and Vector Control Association, Annaheim, January 20-23, 1980, 69-73, California Mosquito and Vector Control Association, Visalia, California.

Pasteur N., Iseki A., Georghiou G.P., 1981a. Genetic and biochemical studies on the highly active esterases $\mathrm{A}^{\prime}$ and $\mathrm{B}$ associated with organophosphate resistance in mosquitoes of the Culex pipiens complex. Biochem. Genet., 19, 909-919.

Pasteur N., Sinegre G., Gabinaud A., 1981b. Est-2 and Est-3 polymorphisms in Culex pipiens L. from Southern France in relation to organophosphate resistance. Biochem. Genet., 19, 499-508.

RANASINGHE L.E., 1976. Role of synergists in the selection of specific organophosphorus resistance mechanisms in Culex pipiens quinquefasciatus Say. Ph. D. dissertation, University of California, Riverside, U.S.A.

RANASINGHE L.E., Georghiou G.P., 1979. Comparative modification of insecticide resistance spectrum in Culex pipiens fatigans Wied. by selection with temephos and temephos/synergist combinations. Pestic. Sci., 10, 510-518.

Raymond M., Gaven B., Pasteur N., Sinegre G., 1984. Etude des mécanismes de la résistance aux insecticides organophosphorés à partir de la sélection de quelques souches de Culex pipiens L. du Sud de la France. Genet. Select. Evol. (soumis pour publication).

Villani F., White G.B., Curtis C.F., Miles S.J., 1983. Inheritance and activity of some esterases associated with organophosphate resistance in mosquitoes of the complex Culex pipiens L. (Diptera Culicidae). Bull. Entomol. Res., 73, 153-170. 